\title{
Public Radio in Brazil: Reflections on their original CONDITIONS, CONTEMPORARY SETTING AND CHALLENGES
}

\author{
Elton Bruno Barbosa Pinheiro
}

\begin{abstract}
Clarify the concept of public radio and certain aspects that relate to the original conditions of such stations in Brazil is the main objective of this work. Therefore, structured in four sessions that dialogue and intertwine: the broadcasting and its mission in the public communication; What is a public radio?; Reflections on the genesis of Brazilian public radio; and considerations on the setting and contemporary challenges of public radio. Methodologically, is based on the structural-historical dialectic approach. In theory, is based on the legal provisions of the Brazilian Constitution, guiding documents of Unesco, studies of Brazilian and European researchers on the subject, as well as the notion of European public broadcasting service. In summary, this paper points out that the understanding of the genesis of public radio in the country valuably contributes to the understanding of the challenges that present themselves to such stations; and the contemporary technological scenario appears to be conducive to the reconfiguration of this service in the convergence environment.
\end{abstract}

Keywords

Brazilian public radio; public servisse; broadcasting; convergence

\section{INTRODUCTION $^{1}$}

Tuning the first steps of this study on the Brazilian public radio frequency of the past - relatively recent - of such stations is a complex and risky exercise, but essential, in view of the contribution that it offers so much to the understanding of the present challenges, as to conjecture more solidly the horizon that presents such stations and hence the joint that they have sought to formalize by National Public Radio Communication Network².

It is also a supported methodological option in the structural-historical dialectic approach, contextually, for this study helps to understand that even though the original conditions of the Brazilian public radio, its structure, formation, development and transformations are peculiar complex and, to some extent, surrounded limiters aspects - political, economic, cultural etc. - this is a problem that, according to Pedro Demo, such as "historically engendered [...] can be changed" (Demo, 2012, p. 106 ).

In this sense, the present study is organized into four sessions that intertwine, namely: The broadcasting and its mission in the public communication; What is a public radio?;

\footnotetext{
' This paper elaborates on arguments previously presented by author elsewhere (Pinheiro, 2016).

${ }^{2}$ This study considers that the formalization of the National Network of Public Radio communication is a positive initiative to strengthen this sphere of broadcasting, in view of the requirement that the programming of all the entities making up the network must comply with the principles and objectives public broadcasting, established by Law No. 11.652, of April 7, 2008. It is related to a previous work already published by the author (Pinheiro, 2016).
} 
Reflections on the genesis of Brazilian public radio; Considerations for setting and contemporary challenges of public radio.

This research is based on the conceptual aspects of public broadcasting present in legal provisions of the Brazilian Constitution in Unesco documents, the concept of European public broadcasting service in studies of Brazilian and European researchers in the field as well as in research on the scenario broadcasting in Latin America and a look at the north American studies on the convergence environment.

At the end of this work, worked considerations indicate that the original conditions of the broadcasting service in Brazil and, in turn, the public radio that constitute it, are factors that certainly influence the development and operation of such stations in the scenario today's media. And also that understanding determined these original conditions contribute valuably to the understanding that this is a time - fundamentally marked by constant improvement of information and communication technologies - important and conducive to the reconfiguration of the Brazilian public broadcasting service, especially for adaptation and integration of its public radio the convergence environment.

\section{The BROADCASTING AND ITS MISSION IN THE PUBLIC COMMUNICATION}

Before a specific approach to what is a public radio, it becomes extremely necessary to attempt a reflection on the area in which they are inserted. Thus, it should be noted that the Brazilian radio stations, including the public, are part of the country's Broadcasting Service and it, in turn, comprises both the transmission of sounds (sound broadcasting), and the transmission of sounds and images (television) the which, as shown by the provisions of Law No. 4,117, of August 27, 1962, must be received directly and freely by the general public.

The Brazilian Constitution points to the existence three broadcasting systems in he country - public, state, private - which will be more detailed in the course of this study. However, in particular, the Brazilian public radio fall into the sphere of the public broadcasting service, whose principles and goals were recently established by Law No. 11.652, of April 7, 2008, which was also the Brazil Communications Company (BCC).

When pointing out such considerations it also becomes essential to pass on that this study considers that the nature of the public broadcasting service refers to a larger concept, as pondered Gisele de Oliveira (2014), the Public Communication, which according to Elizabeth Brandão, is a "communicative process that is established among the State, the government and society with the aim of informing for the construction of citizenship" (Brandão, 2012, p. 9); which, as indicated by Jorge Duarte, is "a collective interest instrument to strengthen citizenship" (Duarte, 2012, p. 60); that, as shown by Heloisa Matos, "also involves the citizen's response to initiatives in the flow of communication between the State and society" (Matos, 2012, p. 48).

These definitions of public communication addressed here cooperate, thus, to introduce a more specific discussion about to the public broadcasting service. Therefore, taking into account the first three devices that link the Brazilian legislation - Law no. 4,117, of August 27, 1962; the Art 223 of the Federal Constitution of 1988; and Law No. 
11.652, of April 7, 2008 - it is possible to see certain inaccuracies that permeate the concept of public broadcasting in the country.

Law No. 4,117, of August 27, 1962, which established the Brazilian Telecommunications Code and to this day, although outdated, still regulates the broadcasting sector is questioned by experts in the field, especially by allowing, without the necessary and clear imposition of principles, the private use of the radio spectrum, which is a public good. About this, Daniel Herz, in his study entitled A história secreta da Rede Globo (The secret history of Rede Globo), warned:

Brazilian law broadcasting, including the Brazilian Telecommunications Code (Act 4. 117, of August 27, 1962), is too ambiguous and malleable. More focused on regulation, this legislation is lacking in principles settings. Holding almost exclusively to technical definitions and jurisdiction assignments, the Code does not reflect a broadcasting policy, that is, the broad principles that should guide the rules, their applications and social practices. [...] The code is omitted in the definition of principles to guide the private use of this natural resource in the public domain. The Code could not, or would not, address the profound contradiction between the social possibilities of broadcasting technologies and their private use. (Herz, 1997, p. 209)

Going forward to the 80's of the last century comes to establishing three different broadcasting systems, as shown by the Art 223 of the 1988 Constitution: "the Executive Branch grant and renew concession, permission and authorization for service radio broadcasting and sound and image, observing the principle of complementarity of private systems, public and state". But what effectively would each of these three systems? As they differ? In fact, until today they were not regulated as they should, so that allow a myriad of interpretations, including on the aforementioned concept of complementarity.

Valci Zuculoto believes that the regulation of such systems "would serve to overcome also and mainly the outdated and uncertainties that generate confusion, misuse and lack of truthful, clear and fair policies for national broadcasting" (Zuculoto, 2012, p. 22).

Corroborating this thought of that researcher, endorse the importance of the regulations of the Brazilian broadcasting - in all its systems - in order to eliminate the existing conceptual gaps within the same and fundamentally tune it with the rapid technological development and media observed today, maintaining such a service as a relevant and strategic option for the maintenance of a democratic society.

Still on the need for regulation of the Brazilian broadcasting service, Murilo Ramos (2008) emphasizes the importance and uniqueness of the example of the British and American institutional models, which have in common the central role of the state with the radio and television services from the operation of autonomous regulatory institutions.

Thus, this researcher points out as one of the biggest regulatory challenges to regulations of the Brazilian broadcasting the necessary inspiration in British and North American mold, in the sense that the country's broadcasting service to ensure "the prevalence 
of public over private [...] what [...] requires two simple steps [...] full use of the public service institute for concessions and radio and television permissions, and the establishment of an independent regulatory body" (Ramos, 2008, p. 7), which, as he explains, it is easy to understand legal, but complex articulation and political will of the country.

About the concept of complementarity, present in the aforementioned constitutional text of 1988 Ramos articulates:

In Brazil, the idea, enshrined in the Constitution, supplementary systems - state, public and private - mistakenly separates the public from the state, as if one could exist without the other, and induce a conceptual confusion between state and government, as one could reduce this. Moreover, the idea enshrined in the Constitution insulates the private of the state and the public, as if one could exist without the license and regulatory control of these. (Ramos, 2008, p. 5)

Even with regard to the issue of complementarity, according to Camila Curado and Nelia Del Bianco:

In theory, the state system would provide government services and present to the public the government's point of view as a component of the variety of views of media democracy. The public system also as an important component of the democratic variety would be spokesperson of the company, providing plurality of opinion and cultural diversity without government intermediation or interests of private enterprise. (Curado \& Bianco, 2014, p. 5)

Even in the face of consistent weights both Curado and Bianco (2014), and Ramos (2008) concerning the complementarity, it is believed that some of the biggest challenges for the regulation of the Brazilian broadcasting hold is not only the gap in terms of an official definition nor the observed range of interpretations of the concept, but rather a lack of political will, the result of proselytizing practices unfortunately rooted in the Brazilian government.

Following the direction of the reflection on the legal frameworks, concerning the Brazilian broadcasting on April 7, 2007, in an attempt to combat the doubts within the specific legislation on the subject, the Federal Government, based on Provisional Measure 398 , instituted the Law $n .{ }^{\circ} 11,652$, which is about the principles and objectives of public broadcasting services operated by the executive branch or granted to entities of its indirect administration and is the Empresa Brasil de Comunicação (EBC). This Act may be considered infra contribution so far stronger in relation to an attempt to minimize the shadows cast on the distinction between public, state and private systems of broadcasting.

And despite the complexity and dynamics surrounding both the concept, as the practices and mission of each of the broadcasting systems under Brazilian law, for this study, broadcasting is a practice, in fact, closely linked to the scope of the Public Service whose implementation, according to the Brazilian Federal Constitution of 1988, in 
its Article 175, you can give yourself "directly by the Government or by concession or permission".

In seeking therefore to clarify what is the public broadcasting service and, above all, taking into account what ascertain Law No. 11,652 on this, it is considered possible to advance in the understanding of what is a public radio. After all, articles 2 nd and 3 rd of this Law respectively show the principles and objectives that must be met by the public broadcasters.

It is understood, therefore, that this law directs a considerably more comprehensive and updated understanding of what public broadcasting mainly for pointing out what should differentiate it from other systems, or programming models, financing and management, which are regulated in several articles of this law, namely articles 2, 3 and 8 , on the issue of programming; articles 11 and 32 relating to funding issues; Articles 1220 concerning management issues.

Specifically about what refers to the public broadcasters management model, it is of paramount importance to stress the necessary participation of society in this respect, which, by acting on the advice Curators wins the legitimate right to decide on the guidelines of the stations, ponder, opine and decide on the editorial line of production and programming and, above all, to speak always the fulfillment of the objectives and principles of public broadcasting, provided for in the law that governs it .

It is mister also signal a potential line observed between marking the Law No. 11,652 and the principles (universality, diversity, independence, differentiation); the mandate (to train, inform and entertain); and mission, "enable citizens to be informed about a variety of subjects to acquire new knowledge, always in the context of interesting and attractive programming", established by Unesco (2001, p. 13) for Public Broadcasting.

\section{What is a Public Radio?}

To elucidate the understanding of the concept of broadcasting service and its mission in the public communication, it is possible to address more security for the specific discussion of what is a public radio 3 . To do so, they shall be dialogue with the theoretical thinking of some researchers of this issue in Europe, where this segment of communication is already established and, therefore, can bring light to the structures and Brazilian conjectures on the subject.

In Spain, for example, Manuel Chaparro Escudero, which considers the radio itself, "a bond, a common cause, an individual identifier with its surroundings, with its similar" (Chaparro Escudero, 1998, p. 17) articulates on public radio follows:

It is understood that a public radio station is one that, in budgetary terms, depends on public funds and revenues under the control of management,

\footnotetext{
3 In Brazil, from the point of view of granting model, there are broadcasters (radio and television): a) trade; b) educational, buoyed by Decree-Law 236 of 28 February 1967, Decree No. 2108 of 24 December 1996, and the Ministerial Decree No. 651 of April 15, 1999; and c) Community, established by Law No. 9,612, of February 19. The term "public radio", although officially non-existent in that grants system, however, is used in this work considering, especially those stations whose objectives and principles have consonance with the provisions of Law No. 11,652 of April 7, 2008.
} 
may be generated in other ways. From a less economic point of view, public radio stations have a mission to offer services to the community and its social, cultural and educational, without prioritizing, as in private broadcasting, commercial and speculative aspects. (Chaparro Escudero, 1998, p. 18)

Considering the scope and "massive" performance radio, Chaparro Escudero defines the radio as a media "transcendent" and argues that this means of communication implies a general interest activity for society and therefore can not but be considered a public service. As well as this, another consideration of this author that is supported by this work is that the radio as a public service can not be confused with a service to the public. The latter, as stated in this Spanish researcher, is the model used by the private system.

Thus, it is understood that a public radio is not one that seeks to meet market demands, seeking return or one that forgets the needs and participation.

Accept the standard: radio equal to "service to the public" is equivalent to recognize that the use of a common good and useful to a social majority can be held for their own benefit, considering private a public domain space. In other words, the public service guarantee entails greater commitments and can only exist when the broadcaster activity can be placed above market interests when it seeks to increase the audience for the sake of progress, when it prioritizes the level of information to the audience [...].

(Chaparro Escudero, 1998, p. 19)

Without giving the aspects that must permeate a democratic society, that Spanish researcher also recognizes that the diversity of broadcasting models (public, private, etc.) is necessary, but to dwell on the importance of public radio, has a maximum inspiring to such broadcasters: "competent radio before competitive" (Chaparro Escudero, 1998, p. 19).

Another Spanish researcher with which this study confirms is Mariano Cebrián Herreros. In his "Rádio Pública / Rádio privada" (Public Radio / Private Radio) work, he defines public radio:

Public radio does not own vision, but welcomes all the options in society. It should be the place of concentration of dialogue and social debate, majorities and minorities, without taking sides for any of the proposals. If public radio there should be established as a guarantee of pluralism and designed not exercised, not by the sum of the multiple channels, but within the same channel and each program. (...) A plurality of programs and information with space for all social groups in their contribution to everyday situations development of society and not only in times of conflict. (Cebrián Herreros, 1992, p. 215)

The line observed in the dialogue between the theoretical thinking of the Spanish Chaparro Escudero and Cebrián Herreros is expensive in this study precisely because endorse as the plurality of ideas, participation and democratization are criteria for the 
development of societies and must fundamentally light and permeate practices of public radio, which - in an exercise of synthesis that bolsters what they preach these authors can and should be respected as relevant means of citizen communication, participatory, democratic and transformative.

However, when conducting an approach to the reality of public broadcasting in Latin America, which is contained in the locus of this study, it is possible to perceive situations still far from what they preach European theories about the performance of public radio. It is quite certain that the subcontinent mentioned have political characteristics, specific economic and cultural, with its different broadcasting systems, so, inserted in other contexts, most of which prevail - taking as an example the case of Brazil - private broadcasters commercial character.

Also in this logic, it is known that even in relation to public broadcasting concept, Latin America finds some challenges, as mentioned by Carlos Esch, Nelia Del Bianco and Sonia Moreira, Brazilian researchers:

[...] The development of a common concept for public broadcasting in Latin America is an exciting semantic challenge, but, above all, a difficult political and cultural challenge. The main questions arise from the different conceptions of financing, management systems, social participation opportunities and assimilation of editorial responsibility in the profile of public institutions broadcasting. (Esch, Bianco \& Moreira, 2013, p. 69)

However, these same researchers also recognize that there are already certain actions within the Latin American subcontinent countries related to the reconfiguration of its radio and public TV's, to drive them from a purely state / government vision and insert them in the sphere public broadcasting. These researchers note five changing trends:

Creation of public enterprises in place of centralized state legal structures; establishment of relatively autonomous deliberative councils responsible for supervising the management of the stations; diversification of funding sources in an attempt to reverse the dependence of government resources; and the renewal of the program with opening for independent production. (Esch, Bianco \& Moreira, 2012)

But beyond that, as analyze these same Brazilian researchers, the public mind, for a significant layer of the Latin American population is still narrowly linked to the government and/or the partisan political issues, which, in a way, repels society; and, it can be said that the specific reality of Brazil there is a stereotypical view of public broadcasting as a dedicated communication practice exclusively for the elite, which ends up weakening and weakening the concept, the practice itself and acceptance of public broadcasters in all these realities.

In Brazil, as already noted, the public service broadcasting as an activity that has a specific law regulating it is indeed something relatively new and its still modest performance, which can also be explained/understood by its appearance - between the 
decades of 20 and 30 of the twentieth century - have been given in an environment where business practices and market vision soon overlapped and historically follow prevailing in relation to the broadcasting of public character.

In the search, so, a definition for public radio in the literature on the subject in Brazil, uses strategically a resume conceptual question. In this way, in 2014, Camila Curado and Nelia Del Bianco, to publish the research entitled The Public Broadcasting concept in view of Brazilian researchers show in their results that, despite the difficulties of the authors of Brazil in defining public broadcasting, for the most of them there is a consensus:

[...] It is expected that a public broadcaster is characterized by the diffusion of cultural, educational, artistic, informative and relentless pursuit of fairness and plurality, as well as having heterogeneous programming grid that reflects the cultural diversity of the country. Radio and public character TVs should focus on the quality of information free from any interference, whether commercial or policy of any kind. (Curado \& Bianco, 2014, p. 9)

In summary, it can be said that a public radio should be characterized as a means and democratic means of communication, in which programming models, management and financing must be in line with the objectives, principles, mission and mandate of public broadcasting.

In order words, a public radio station is one that differs in its programming, seeking appreciate the direct participation of society in its management; It is at the same time, autonomous and supervised the fulfillment of its purposes; It has editorial independence in the development of its content and programming, while remaining attractive, plural, diverse, differentiated, closer to the citizen; and a transparent public financing system, non-commercial but creative and, as far as possible, dynamic, to be open to search the covenants provided for by law.

Furthermore, another aspect should mark out, in general, a public radio today is the dialogue that they must keep up with the changes of information and communication technologies, especially with the reality of convergence environment, under penalty of being relegated front to devices and today's media practices.

Adaptation and integration of public Brazilian radio stations to the convergence of environment can be seen, therefore, as the major challenges to be overcome by these stations, which can be better understood and justified if they are taken into account specific conditions of origin of these broadcasters in the country.

\section{REFLECTIONS ON THE GENESIS OF BRAZILIAN PUBLIC RADIO}

The history of radio broadcasting in Brazil is on the eve of its centenary, since the creation of the first Brazilian broadcaster to officially enter the air, the Radio Society of Rio de Janeiro, took place in 1923 thanks mainly to Edgard Roquette-Pinto. However, in a particular way, the genesis of public radio stations in the country refers more strongly to the year 1936, around 80 years when Roquette-Pinto, to donate the Radio Society of Rio 
de Janeiro to the then Ministry of Education and health for lack of financial resources to maintain it, officially asked the Brazilian federal government conservation educational and cultural aspect of the station.

The year 1936 also marks the start of activities, even with commercial character, of the National Radio of Rio de Janeiro and Radio Cultura of São Paulo, which were nationalized, respectively, in 1940 and 1969, with the detail of the Radio national, even through the control of the government of President Getulio Vargas, remained with its activities focused on the business model, and, yet, recognized at the time as standard country radio (Zuculoto, 2012). Currently, the National Radio of Rio de Janeiro is part of the public system of Brazil Communications Company Radio.

After highlighting the events that signal the start of broadcasting activities in Brasil a sense of historicity must be added in order to better understand both what shaped and what might still condition public radio services in the country.

Such an exercise can be performed with the help of two studies: Bloom FM Education in Brazil: Radiography of educational radio in Brazil and the factors favorable to the occupation of educational FM channels, by Marlene Blois (1996), and The schedule of Brazilian public radio, by Valci Zuculoto (2012). Both Blois as Zuculoto use historical categorizations as a methodological strategy in their respective studies.

However, unlike the contributions of these authors, the objective of the approach to be carried out here is not to establish / discuss historic radio phases - exercises that are undoubtedly relevant - but systematizing the understanding of certain facts that over the years of existence of the broadcasting service in the country can, even if understood in a nonlinear way, be contributing or hindering the routing of Brazilian public radio for insertion in today's media landscape, marked by changes of communication and information technology, especially the convergence environment. In this sense, three facts are worth mentioning.

First of all, the origin of the Brazilian public radio is linked to the emergence of educational broadcasting service, which, in turn, was born before they are established criteria or official standards that differentiate the trading system of non-commercial.

However, it is very important to note that the origin of the educational system of Brazilian radio, which currently has the clear mission: "the transmission of educational and cultural programs, [...], for the promotion and strengthening of basic education and higher, permanent education and educational, cultural, educational and vocational guidance disclosure" (Educational Broadcasting, 2014), refers to a period in which the country, and also of Latin America, seeking, in a post-war period, overcome complex social challenges, above all, the high illiteracy rate of the population and, therefore, betting on the dissemination of science, art and culture through the radio.

João Batista de Abreu, analyzed this scenario in the Latin American subcontinent, reveals another peculiarity that, in its opinion, also contributed to the emergence of the educational radio system, the role and influence of the Catholic Church. According to this researcher, "the high rates of illiteracy, large distances and uneven social and geographical distribution lead governments and secular and religious educators to see the sound waves one inexpensive alternative to propagate knowledge" (Abreu, 2004, p. 1). 
Taking into consideration what ponder: a) Mario Kaplún, on "the media [...] as a transformer feeders educational process" in which "every kind of education corresponds to a certain conception and a certain practice of communication" (Kaplún, 1985); and b) Juan Bordanave on the existence of three basic models of education: "that emphasizes the content, which prioritizes results and that values the learning process" (Bordanave quoted in Kaplún, 1985).

It can be inferred that, in relation to the mentioned educational models, all these were, at some point in the daily routine of educational broadcasting in Brazil and other Latin American countries, which was realized in times where this segment broadcasting, They prevailed: i) simple diffusion of content; or ii) the search for overcoming poverty and the consequent economic progress of the country, the intellectual view of the time needed to modernize; or, iii) the desire, in fact, develop critical and intellectual capacity of citizens and social awareness of these (Abreu, 2004).

In Brazil, the pioneer of radio educational segment, Roquette-Pinto, envisioned, even in the 20 s of the last century, through the radio, "work culture and the progress of those living in our land". Nevertheless, his ideas and actions, even if far from the impositions of the business model also had a noticeable elitist-erudite character, which can be understood as one of the reasons why the popularization of educational radio, despite the significant social function, has found obstacles, contextually, they reverberate today, when seeking the consolidation and spread of proper public broadcasting in a new media landscape.

This point of view highlights that the backgound for the emergence of educational radio in the country was also anchored in the objectives of the Brazilian military regime, which "sought to exploit this potential of education and radio in defense of their interests" (Zuculoto, 2012, p. 132).

Thus, observing more closely the beginnings of Brazilian educational radio, it is clear that acquiring this educational bias was not only "a commitment to citizenship which education is part" (Blois, 2004, p. 147), but also a strategy directly linked to the political and social context of the time and the desire for economic development, which involved not only Brazil, but, notably Latin America.

Also draws attention to this fact the question that Brazilian educational stations generally managed by the state and surrounded by a political thought which seeks to promote the idea of education and development, present in the understanding of this study, from the time of pioneering Radio Society Rio Janeiro, now called Radio MEC, two obstacles related to its structure and performance:

a) the training of its staff of technical professionals, made over the years by public servants who, not surprisingly, are immersed in an organizational culture in which, generally, for the stability of their positions, do not specialize or update forward to technological changes and other demands of society, as the reinvention of the relationship with the audience, which includes democratic and active participation of citizens, for example, in the production and / or reverberation content and inventive inclusion of stations in the social environment networks digital etc.

b) the poor technical conditions in which these radios operated and, in some cases, still operate, or delayed in relation to the constant technological reconfigurations, not favoring the dialogue of public radio with other media platforms, which hampers the necessary inclusion of such stations in the convergence environment. 
Secondly, it is possible to emphasize that, despite a public origin, although "implied", Brazilian radios soon became mostly commercial media.

The way they gave the official start of broadcasting activities in Brazil - in 1922, with the inaugural broadcast radio marked by a speech by then president Pessoa - shows the beginning of a performance of the radio medium in a context that already approaches the concept of public service, either because of the first transmissions are already linked to the support the government, or because they have already in their origin primate mission to educate, inform and disseminate culture.

Nevertheless, this public purpose present in the root of the pioneers of radio in Brazil was soon overcome with commercial views, as analyzes José Roberto Garcez, "and so it was that the radio was forming in Brazil. Public, even if unconsciously for some, but for private ownership that it did those who saw him as profit tool and leverage personal prestige" (Garcez, 2012, p. 14).

A third fact to be emphasized is that the lack of regulation of the Law on broadcasting service has given several stations enough space to self-appoint themselves as public.

The early 2000s, in a way, strongly mark the impacts caused by lack of regulation of the Brazilian legislation in relation to the broadcasting service, which, in the opinion of this study, it is also one of the strong reasons for broadcasters to then inserted both in the education system - academic and cultural - as the state themselves to a self-named "public".

In this period and context in which different segments of the radio broadcasting begin to call themselves "public" - taking into account only the characteristics of their schedules (Zuculoto, 2012) - means, on the one hand, a vision, in a sense, incomplete on the concept of "public broadcasting" and, second, an opportunity observed by these stations to begin to see, in terms contemplated / supported by a service that goes to organize more solidly from the Law No. 11.652 of 07 April 2008, establishing the principles and objectives of public broadcasting services operated by the executive branch or granted to entities of its indirect administration and authorized the Executive Branch to be the Empresa Brasil de Comunicação (EBC).

In general, however, it is undeniable that the embryo of Brazilian public radio is closely linked to the relevant activities of the cultural, educational, university and state broadcasters, but in particular due to the pursuit of certain independence of the same in terms of the diversity of their schedules (Zuculoto, 2012). Still, for a station is considered, in fact, public, besides the differential bias programming, other aspects need to be taken into account such as the management model and sources of funding, nor is it enough that if self proclaimed public the fact that they are outside the commercial line.

No doubt, these are facts that somehow have shed light on some of the aspects that help to understand why it has become a challenge for the Brazilian public broadcasting service, particularly for its radio stations, adapt and integrate into convergence environment. Added to these conditions here scored, are presented, then additional considerations that help you understand the current situation and challenges of Brazilian public radio. 


\section{CONSIDERATIONS FOR SETTING AND CONTEMPORARY CHALLENGES OF PUBLIC RADIO}

In this final topic of this work some considerations that may be critical to understanding the contemporary scene in which the Brazilian public radio is framed are presented in the form of questions.

Question 1: Is it possible to distinguish different conceptions of what is public service broadcasting? The answer is yes and must, above all, the state's role model in this area. In particular, this study finds that two of these models need to be understood and taken into account for the increase of the Brazilian public broadcasting service.

The first is the public service, European (British) origin, which, in general, the state provides and funds this service without commercial intentions, keeping it through taxes arising, for example, the sale of radio and television. In this model the state regulates the public broadcasting by an independent body, responsible also for the UK communications industries, the Office of Communication.

The other model is the public interest of the American root, which, in summary, broadcasting services are provided by the private sector but under state regulation and supervision. In this model the forms of financing are arising from different sources, for example, governments (federal, state and local), foundations, public entities broadcasters, corporations and individual donations. Already the management of organizations who make up such a model is carried out by boards.

Resuming the answer to that first question we see that there is, in fact, different views on the idea of what is, in general, public broadcasting, which is not to say that there is no dialogue between them. However, it is not advisable to ignore or confuse such views. So, you can also take into consideration the specific case of the Brazilian public service may still be inserted into a middle ground between these British and American concepts as indicated by some researchers in the field, as Suzy Santos and Erico da Silveira (2007). However, an important first step and safe for those who want to understand, for example, challenges and present and future possibilities of Brazilian public radio is, undoubtedly, be aware of these different positions mentioned, considered exemplary in the world.

Question 2: Is there some of these approaches mentioned in Question 1 may be considered more relevant to bring light to the Brazilian public broadcasting in the contemporary scene? The answer is yes. Although both the British model as the US provide for the state's role as regulator, the European approach 4 is more heuristics, in other words, is closer to the desires of Brazilian society - perceptibly Academy - for public service broadcasting the country, especially by the example of society's conditions of participation in their management,

\footnotetext{
${ }_{4}$ This study recognizes that, broadly, the concept of public service in European law framework, as discussed by Monica Justen, "has a variant trajectory, now enjoying high prestige the point of being considered a cornerstone of Administrative Law, now being treated as an idea difficult to understand, devoid of legal significance" (Justen, 2003, p. 11). Said Brazilian researcher comes to realize that the concept of public service in Europe has acquired a certain aspect "mythological, of elusive and nebulous concept". However, when being the European concept of public service as one that can bring light to the Brazilian case, this study relies on the fact that communications across Europe, "were placed as fueling, or at least as extensions of cultural and educational activities" (Santos \& Silveira, 2007, p. 79) and refers mainly to the model of British public broadcasting, which gives the state a great responsibility in the provision, regulation and financing of such a service, and provides relevant forms of participation of society in its management model.
} 
which occurs, for example, by participating in councils, committees and also through consultations and public debates.

Of course, the British view also has, if thought an application to the Brazilian context, some revisable points when considering, for example, the question of its financing model, which provides between one of its sources the payment of a fee annual per possessor of radio or television, called license fee, which seems unworkable in a country like Brazil where the public notion of this culturally between society is closely linked to gratuitousness.

With regard to the activities of public radio stations belonging to the British model, such channels have more interesting for the Brazilian reality is the fact that, as stated Jonas Valente, "end up there due to certain specific content and operate their schedule based on this prerogative" (Valente, 2009, p. 246). That is, there is an appreciation of hypersegmentation and hyper-specialization of their schedules, but without forgetting the value of local character content and / or regional.

Question 3: Are the educational and cultural purposes only principles and objectives of public broadcasting? The answer is that these are to ultimate objectives, namely primary, which information services are subordinate, fun etc. the broadcasters of the country in general, as noted in item "d" of Art. No. 38 of Law No. 4,117. The Public Broadcasting Service, above all, from the radio, which is a medium with significant activity in the daily life of a significant layer of the population, should not be limited in order to stifle their programming for the elite standardizing their content. Local culture, the collective construction of knowledge, information and entertainment should also be prioritized.

It should be emphasized, therefore, that public broadcasters should be understood in its triple mandate to inform, educate and entertain. Still, you want this communicational field get due prominence on the current media landscape, it means not restrict her mission only to the educational bias, as it is possible to realize in many cases. As suggested by Unesco (2001, p. 13), it should be noted that public broadcasting "must do things differently", which radio is even easier, especially the primate approach said means has with citizens but still, actions like this require thorough planning.

Question 4: Have the public radios occupied that position type in the current context of the Public Broadcasting Service in Brazil? Taking up the issue: are the Brazilian public radio, in relation to public television stations in the country, also prioritized for the actions and / or plans of the public system?

The answer is no. Taking as an example the stations managed by the Brazil Communications Company and the actions planned for its radio system and, although a brief explanation about the analysis in the latest Work Plan of the EBC, 2015, it is observed that it which is proposed specifically for their radios refers solely to the issue of organizational logic of the redefinition of stations by affinity axes (axis 1 - News, sports and public service; axis 2 Educational, collaborative and experimental; axis 3 - cultural and musical).

Besides, the document mentioned surface points to the need to monitor and act on the decisions of the new scenario of Brazilian radio in relation to new technologies, particularly the issues related to digital radio.

Anyway, there is arguably no concrete planning on a model or strategy plan in terms 
of integration of public radio in the current media landscape, marked by rapid and constant change of information and communication technologies and the demands of the environment convergence.

Question 5: Should the role of public radio in the current media landscape be planned / articulated alone? Or should this action take into account the possibilities of convergence?

Certainly, the public radio should now act in accordance with that which can not be ignored: the convergence of the environment, which means that, especially your schedule should excel for content that is accessible, spread, up from crossing and / or dialogue with different communication formats and have a vibrant citizen participation in this process, which can not be reduced to mere recipient but an active collaborator, able not only to access, but to produce, share and spread the contents in several media platforms, creating, as suggested by Henry Jenkins, Joshua Green and Sam Ford (2014) more value and meaning for them and for the public broadcasting itself.

The big contemporary challenge in this regard is that the Brazilian public radio adapt and integrate this converged environment. An effort that this study believes can be overcome from the necessary understanding and overcoming of certain aspects of the conditions of origin of these broadcasters, like those here elucidated.

\section{JURIDIC REFERENCES}

Abreu, J. B. (2004). Nas ondas da fé. In Anais do II Encontro Nacional da Rede Alfredo de Carvalho, Florianópolis. Retrieved from http://www.ufrgs.br/alcar/encontros-nacionais-1/encontros-nacionais/20encontro-2004-1/Nas\%20ondas\%20da\%2ofe.doc.

Brandão, E. P. (2012). Conceito de comunicação pública. In J. Duarte (Ed.), Comunicação Pública: Estado, mercado, sociedade e interesse público (pp. 1-33). São Paulo: Atlas.

Blois, M. (1996). Florescem as FM Educativas no Brasil. Radiografia do radioeducativo no Brasil e os fatores favoráveis à ocupação dos canais de FM educativos. Tese de Livre-Docência em Comunicação Televisão e Rádio. Universidade Gama Filho, Rio de Janeiro, Brasil.

Cebrián Herreros, M. (1992). Radio Pública / Radio Privada. In Comunicación Social 1992 / Tendências. Madrid: Fundesco.

Chaparro Escudero, M. (1998). Radio pública local. Sevilla: Fragua.

Curado, C. M. \& Bianco, N. R. del. (2014). O Conceito de Radiodifusão Pública na visão de pesquisadores brasileiros. In Anais do XXXVII Congresso Brasileiro de Ciências da Comunicação, Foz do Iguaçu, Paraná, Brasil. São Paulo: Intercom.

Demo, P. (2012). Metodologia do Conhecimento Científico. São Paulo: Atlas.

Duarte, J. (2012). Instrumentos de comunicação pública. In J. Duarte (Ed.), Comunicação Pública: Estado, mercado, sociedade e interesse público (pp. 59-71). São Paulo: Atlas.

Esch, C. E., Bianco, N. R. del \& Moreira, S. V. (2013). Radiodifusão pública: um desafio conceitual na América Latina. Revista FSA, 10, 67-86. 
Garcez, J. R. (2012). Contribuição para refletir sobre um “modelo brasileiro" de rádio pública. In V. R. M. Zuculoto (Ed.), A programação de Rádios Públicas Brasileira. Florianópolis: Insular.

Herz, D. (1997). A história secreta da Rede Globo. Porto Alegre: Ortiz.

Jenkins, H., Green, J. \& Ford, S. (2014). Cultura da conexão: criando valor e significado por meio da mídia propagável. São Paulo: Aleph.

Justen, M. S. (2003). A noção de serviço público no direito europeu. São Paulo: Dialética.

Kaplún, M. (1985). O comunicador popular. Parte I. Ciespal, Quito. Retrieved from https://www.passeidireto. com/arquivo/1944031/o-comunicador-popular---kaplun-capı

Matos, H. (2012). Comunicação pública, esfera pública e capital social. In J. Duarte. (Ed.), Comunicação Pública: Estado, mercado, sociedade e interesse público (pp. 47-58). São Paulo: Atlas.

Oliveira, G. P. (2014). Rádio e Internet: o uso de sites pelas emissoras públicas de radiodifusão sonora. Dissertação de Mestrado, Universidade de Brasília, Brasília, Brasil.

Pinheiro, E. (2016). Serviço de Radiodifusão Pública no Brasil: considerações sobre suas condições de origem e perspectivas. Revista Rádio-Leituras, o7(1), pp. 35-59. Retrieved from http://www.periodicos. ufop.br/pp/index.php/radio-leituras/article/view/173.

Santos, S. \& Silveira, É. (2007). Serviço Público e Interesse Público nas Comunicações. In M. C. Ramos \& S. Santos (Eds.), Políticas de Comunicação. Buscas teóricas e práticas (pp. 49-82). São Paulo: Paulus.

Valente, J. (2009) Sistema Público de Comunicação do Reino Unido. In Z. Tolnon (Ed.), Sistemas públicos de comunicação no mundo: experiência de doze países e o caso brasileiro. São Paulo: Paulus, Intervozes.

Zuculoto, V. R. M. (2012). A programação de Rádios Públicas Brasileira. Florianópolis: Insular.

\section{OTHER REFERENCES}

Brasil. (1988). Constituição da República Federativa do Brasil. Brasília: Senado Federal.

Decreto $n^{\circ}$ 52.795, de 31 de outubro de 1963. Presidência da República. Casa Civil. Subchefia para Assuntos Jurídicos. Brasil.

Decreto $n^{\circ}$ 52.026, de 20 de maio de 1963. Presidência da República. Casa Civil. Subchefia para Assuntos Jurídicos. Brasil.

Lei $n^{\circ}$ 11.652, de 07 de abril de 2008. Presidência da República. Casa Civil. Subchefia para Assuntos Jurídicos. Brasil.

Lei $n^{\circ}$ 4.117, de 27 de agosto de 1962. Presidência da República. Casa Civil. Subchefia para Assuntos Jurídicos. Brasil.

Portaria $n^{\circ}$, de 17 de janeiro de 2014. Ministério das Comunicações. Brasil.

Plano de Trabalho EBC. (2015). Conteúdo e programação - Diretrizes e perspectivas. Retrieved from http:// conselhocurador.ebc.com.br/sites/_conselhocurador/files/resolucao_02_2015_-_aprovacao_do_plano_ de_trabalho_2015_com_o_plano.pdf.

Radiodifusão Educativa e Consignações da União. (2014). Apresentação. Retrieved from http://www. comunicacoes.gov.br/espaco-do-radiodifusor/radiodifusao-educativa-e-consignacoes-da-uniao 
Ramos, M. C. (2008). Reestruturação do sistema e controle público. Retrieved from http://www.fndc.org.br/ search/?q=Reestrutura\% $3 \% \mathrm{~A}_{7} \% \mathrm{C}_{3} \% \mathrm{~A}_{3} \mathrm{O}+$ do+sistema.

Unesco. (2001). Public Broadcasting: Why? How? Retrieved from http://unesdoc.unesco.org/ images/0012/001240/124058Eo.pdf.

\section{BIOGRAPHICAL NOTE}

Elton Bruno Barbosa Pinheiro is a doctoral student in Communication at the University of Brasilia (UNB). Master in Communication \& Culture media and Bachelor of Social Communication at the Federal University of Paraiba (UFPB). Researcher at the Centre for Public Broadcasting in Latin America and the Research Group on Radio Sonora and Media of the Brazilian Society of Interdisciplinary Studies of Communication.

E-mail: eltonbrunopinheiro@gmail.com

Universidade de Brasília - UnB

SHIGS, Qd. 709, Bl. Q, n ${ }^{12}$, Asa Sul

Brasília - DF, 70.360-717, Brazil

* Submitted: 12-03-2016

* Accepted: 14-04-2016 